\title{
Особливості порушень ліпідного обміну у хворих на червоний плоский лишай
}

\author{
А.М. Біловол, Н.Л. Колганова \\ Харківський національний медичний університет
}

\begin{abstract}
Резюме
Наявність захворювань травного тракту, метаболічних порушень, ендокринної патології впливає на характер перебігухронічних дерматозів і формування клінічної симптоматики.

Мета, матеріали та методи. Устатті наведено оцінку вмісту рівнів деяких показників ліпідного профілю(загального холестерину [ЗХ], холестерин-ліпопротеїдів низької щільності [ХС ЛПНЩ] та холестерин-ліпопротеїдів високої щільності [ХС ЛПВЩ]) у хворих на типові та атипові форми червоного плоского лишаю (ЧПЛ). Під наглядом перебували 59 пацієнтів з ЧПЛ віком від 18 до 67 років. Контрольну групу становили 18 практично здорових осіб репрезентативних за віком і статтю.
\end{abstract}

Результати та висновки. Встановлено підвищення рівнів ЗХ та ХС ЛПНЩ ухворих на ЧПЛ.

Ключові слова: червоний плоский лишай, супутня патологія, ліпідний профіль, типові та атипові форми червоного плоского лишаю.

DOI: 10.33743/ 2308-1066-2019-3-13-14

Червоний плоский лишай (ЧПЛ), незважаючи на довгу історію вивчення, залишається істотною проблемою сучасної дерматології. Натепер ЧПЛ прийнято розглядати як ідіопатичне хронічне запальне захворювання шкіри та слизових оболонок. За даними епідеміологічних досліджень, ЧПЛ зустрічається у 1-2\% населення земної кулі, частіше в жінок віком від 40 до 65 років [3, 9, 10]. Кількість хворих на ЧПЛ має тенденцію до зростання, незважаючи на сучасні методи діагностики та лікування, відзначається збільшення форм ЧПЛ торпідних до терапії [1, 9, 11].

У разі ЧПЛ частіше страждає шкіра (50-75\%), але в 25\% випадків зустрічається ізольоване ураження слизових оболонок порожнини рота. У 1-13\% хворих спостерігається ізольоване ураження нігтів $[1,5,6,9,10]$. Залежно від тяжкості та локалізації висипу на шкірі хворі можуть відчувати значний фізичний і психологічний дискомфорт, труднощі з соціальною та професійною адаптацією, спостерігається значне зниження якості їхнього життя $[2,5,10]$.

Відомо, що наявність захворювань травного тракту, метаболічних порушень, ендокринної патології впливає на характер перебігу дерматозу та формування клінічної симптоматики. У патогенезі багатьох хронічних дерматозів важлива роль належить порушенням жирового та вуглеводного обмінів речовин, порушенням у системі антиоксидантного захисту. Так, у хворих на псоріаз, екзему, атопічний дерматит відмічають порушення ліпідного, білкового обмінів у вигляді підвищення рівня загальних ліпідів, гіперхолестеринемії, порушення рівноваги жовчних кислот, активності печінкових ферментів тощо [4, 6, 7, 8]. Водночас питання порушення ліпідного обміну при ЧПЛ залишається дискутабельним і до кінця не вивченим.

Мета дослідження: вивчити ліпідний профіль у хворих на ЧПЛ в залежності від клінічної форми захворювання.

\section{Матеріали та методи дослідження}

Під наглядом перебувало 59 пацієнтів (36 жінок [61\%] і 23 чоловіки [39\%]) з ЧПЛ, які проходили стаціонарне лікування в Харківському міському клінічному шкірно-венерологічному диспансері № 5. Середній вік хворих становив $60,8 \pm 2,6$ року. Критеріями включення до груп були: вік пацієнтів від 18 до 67 років, верифікований діагноз ЧПЛ, згода на участь у дослідженні. Критерії виключення: хворі з декомпенсованими станами, хронічними захворюваннями в стадії загострення.

Усіх пацієнтів було розподілено на 2 групи: I групу (33 особи) становили пацієнти з типовою формою ЧПЛ, до II групу (26 осіб) - з атиповими формами ЧПЛ (лінійною, пігментною, верукозною, гіперкератотичною та атрофічною). Група контролю складалась з 18 практично здорових осіб репрезентативних за віком і статтю. Супутню патологію було встановлено у 38 (64,4\%) хворих. Серед хворих на ЧПЛ у 19 пацієнтів (50\%) виявлено ураження серцево-судинної системи (стенокардія спокою та напруги, ішемічна хвороба серця, гіпертонічна хвороба I-II ступенів), у 15 (39,5\%) - патологію травного тракту (хронічний гастрит і гастродуоденіт у стадії неповної ремісії, виразкова хвороба шлунка та дванадцятипалої кишки, хронічний холецистит, хронічний панкреатит), у 4 осіб (10,5\%) - порушення нервової системи (астено-невротичний синдром, тривожність).

Дослідження ліпідного обміну проводили шляхом оцінки рівня загального холестерину (3Х), холестерин-ліпопротеїдів низької щільності (ХС ЛПНЩ) та холестерин-ліпопротеїдів високої щільності (ХС ЛПВЩ). Визначення концентрації $3 \mathrm{X}$ у сироватці крові пацієнтів проводили за допомогою комерційної тест-системи фірми «СпайнЛаб» (Україна) на біохімічному аналізаторі Labline-80 (Австрія). Визначення рівня ХС ЛПНЩ і ХС ЛПВЩ у сироватці крові хворих проводили за допомогою комерційної тест-системи фірми DAC-SpectroMed (Молдова) на біохімічному аналізаторі Labline-80 (Австрія). Статистичний аналіз даних проводили за допомогою комп'ютерної програми Microsoft Excel 2010. Застосовували методи описової статистики з обчисленням середньої арифметичної (М), похибки середньої арифметичної (m), середнього квадратичного відхилення 
$(\sigma)$. Ступінь достовірності відмінності показників визначали за допомогою t-критерію Стьюдента.

\section{Результати та їх обговорення}

Результати дослідження рівнів 3Х, ХС ЛПНЩ та ХС ЛПВЩ в сироватці крові хворих на ЧПЛ i здорових добровольців наведені в таблиці.

таблиця. Рівень 3X, XС лпнщ та ХС лпвщ в сироватці крові хворих на чПЛ в залежності від клінічної форми захворювання

\begin{tabular}{|c|c|c|c|}
\hline Група & $3 x$ & хс лпнщ & хс лпвщ \\
\hline I група $(n=33)$ & $\begin{array}{c}6,28 \pm 0,19 \\
p \leq 0,05\end{array}$ & $\begin{array}{c}4,88 \pm 0,2 \\
p \leq 0,05\end{array}$ & $\begin{array}{l}1,1 \pm 0,05 \\
p \geq 0,05\end{array}$ \\
\hline II група $(\mathrm{n}=26)$ & $\begin{array}{c}5,75 \pm 0,14 \\
p \geq 0,05\end{array}$ & $\begin{array}{c}4,37 \pm 0,15 \\
p \geq 0,05\end{array}$ & $\begin{array}{c}1,21 \pm 0,05 \\
p \geq 0,05\end{array}$ \\
\hline $\begin{array}{l}\text { Контрольна } \\
\text { група }(\mathrm{n}=15)\end{array}$ & $4,64 \pm 0,24$ & $3,84 \pm 0,16$ & $1,16 \pm 0,07$ \\
\hline
\end{tabular}

Примітка: $p$ - достовірна різниця значень при порівнянні з показниками контрольної групи.

\section{Список літератури}

1. Довжанский С.И., Слесаренко Н.А. Клиника, иммунопатогенез и терапия красного плоского лишая. Русский медицинский журнал. 1998. № 6. С. 348-350.

2. Дороженок И.Ю., Снарская Е.С., Шенберг В.Г. Красный плоский лишай и ассоциированные психосоматические расстройства. Вестник дерматологии и венерологии. иров. № 4. С. 27-32.

3. КачукЮ.В. Червоний плескатий лишай: клінічні та терапевтичні аспекти. Східноєвропейський журнал внутрішньої та сімейної медицини. 2015. № 2. С. 69-74.

4. Коморбидность при красном плоском лишае /Н.А. Слесаренко, С.Р. Утц, Е.М. Артемина, Ю.М. Штода, Е.Н. Карпова. Клиническая дерматология и венерология. 2014. № 5. С. 4-10.

5. Мельник Т.В., Бондар С.А., ГаврилюкА.О. Сучасні патогенетичні аспекти та методи лікування червоного плоского

6. Молочков В.А., Сухова Т.Е., Молочкова Ю.В. Клинические особенности красного плоского лишая. Клиническая дерматология и венерология. 2013. № 11(4). С. 34-43.

7. Паращук Б.М., Калюжна Л.Д. Стан пероксидного окислення ліпідів у хворих на мікробну екзему. Дерматологія та венерологія. 2009. № 1(43). С. 38-41.

8. Фоменко С.Е., Кушнерова Н.Ф., Спрыгин Е.Г. Коррекция нарушений липидного обмена и антиоксидантной активности у больных псориазом. Pacific Medical Journal. 2006. № 4. С. 74-77. 9. Lichen planus: molecular pathway and clinical implications in oral disorders / M. Boccelino, D. Di Stasio, A. Romano [et al.]. J Biol Regul Homeost Agents. 2018. Vol. 32 (2 Suppl. 1). P. 135-138. 10. Oral lichen planus: a narrative review / D. Di Stasio, A. Guida, C. Salemo [et al.]. Front Biosci. 2014, № 6. P. 370-376.

11. Vulvovaginal gingival lichen planus: report of two cases and review of literature / A. Lucchese, A. Dolci, G. Menervini [et al.]. Oral Implantol (Rome). 2016. № 9. P. 54-60. doi: org/10.11138/orl.2016.9.2.054
Як свідчать дані таблиці, під час біохімічного дослідження у хворих обох груп були виявлені порушення ліпідного профілю. Порівняно з показниками контрольної групи в пацієнтів I групи достовірно $(\mathrm{p} \leq 0,05)$ були підвищені рівні $3 \mathrm{X}$ та ХС ЛПНЩ в 1,35 та 1,27 раза відповідно; у хворих II групи спостерігалася тенденція до підвищення концентрації 3Х та ХС ЛПНЩ. Рівень показників ХС ЛПВЩ у групах пацієнтів порівняно з групою контролю майже не відрізнявся.

\section{Висновки}

У хворих як на типові, так і на атипові форми ЧПЛ спостерігають порушення ліпідного обміну у вигляді підвищення рівнів ЗХ та ХС ЛПНЩ, що, безумовно, є обтяжуючим фактором перебігу дерматозу. Даний факт слід враховувати під час патогенетичного обгрунтування призначуваної терапії.

\section{References}

1. Dovzhansky SI, Slesarenko NA. Klinika, immunopatogenez i terapiya krasnogo ploskogo lishaya Clinic, immunopathogenesis and treatment of lichen planus]. Russkiy meditsinskiy zhurnal. 1998;6:348350.

2. Dorozhenok IY, Snarskaya ES, Shenberg VG. Krasnyiy ploskiy lishay i assotsiirovannyie psihosomaticheskie rasstroystva [Lichen planus and associated psychosomatic disorders]. Vestnik dermatologii i venerologii. 2016;4:27-32.

3. Kachuk YV. Chervonyi pleskatyi lyshay: klinichni ta terapevtichni aspekty [Lichen planus: clinical

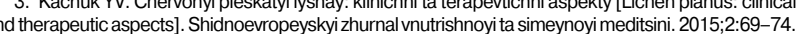
4. Slesarenko NA, Utts SR, Artemina EM, et al. Komorbidnost pri krasnom ploskom lishae [Comorbidity with lichen planus]. Klinicheskaya dermatologiya i venerologiya. 2014;5:4-10.

5. Melnik TV, Bondar SA, Havryliuk AO. Suchasni patogenetychni aspektyta metody likuvannya cher5. Melnik TV, Bondar SA, Havryliuk AO. Suchasni patogenetychni aspekty ta metody likuvannya cher-
vonogo ploskogo lishayu [Modern pathogenetic aspects and methods of treatment of lichen planus]. vonogo ploskogo lishayu [Modern pathogenetic aspects and methods of treatm.
Visnyk Vinnytskogo natsionalnogo medychnogo universytetu. 2017;2:553-557.

6. Molochkov VA, Suhova TE, Molochkova YV. Klinicheskie osobennosti krasnogo ploskogo lishaya
ny Clinical features of lichen planus]. Klinicheskaya dermatologiya i venerologiya. 2013;11(4):34-43. 7. Paraschuk BM, Kalyuzhna LD. Stan peroksidnogo okislennya lipidiv u hvoryh na mikrobnu ekzemu [State of lipid peroxidation in patients with microbial eczema]. Dermatologiya ta venerologiya. 2009;1(43):38-41.

8. Fomenko SE, Kushnerova NF, Spryigin EG. Korrektsiya narusheniy lipidnogo obmena i antioksidantnoy aktivnosti u bolnyih psoriazom [Correction of lipid metabolism and antioxidant activity in patients with psoriasis]. Pacific Medical Journal. 2006;4:74-77.

9. Boccelino M, Di Stasio D, Romano A, et al. Lichen planus: molecular pathway and clinical implicans in oral disorders. J Biol Regul Homeost Agents. 2018;32 (2 Suppl. 1):135-138.

10. Di Stasio D, Guida A, Salemo C, et al. Oral lichen planus: a narrative review. Front Biosci. 2014;6:370-376.

11. Lucchese A, Dolci A, Menervini G, et al. Vulvovaginal gingival lichen planus: report of two cases and review of literature. Oral Implantol (Rome). 2016;9:54-60. doi: org/ 10.11138/orl.2016.9.2.054.

\section{ОСОБЕННОСТИ НАРУШЕНИЙ ЛИПИДНОГО ОБМЕНА У БОЛЬНЫХ КРАСНЫМ ПЛОСКИМ ЛИШАЕМ}

А.Н. Беловол, Н.Л. Колганова

Харьковский национальный медицинский университет

\section{Резюме}

Наличие заболеваний пищеварительного тракта, метаболических нарушений, эндокринной патологии влияет на характер течения хронических дерматозов и формирование клинической симптоматики.

Цель, материалы и методы. В данной статье приведена оценка содержания уровней некоторых показателей липидного профиля (общего холестерина [OХ], ХС-ЛПНП и ХС ЛПВП) у больных типичными и атипичными формами красного плоского лишая (КПЛ). Под наблюдением находились 59 пациентов с КПЛ в возрасте от 18 до 67 лет. Контрольную группу составили 18 практически здоровых лиц репрезентативных по возрастуи полу.

Результаты и выводы. Установлено повышение уровней ОХи ХС ЛПНПу больныхКПЛ.

Ключевые слова: красный плоский лишай, сопутствующая патология, липидный профиль, типичные и атипичные формы красного плоского лишая.

\section{LIPID METABOLISM DISORDERS FEATURES IN PATIENTS WITH LICHEN PLANUS}

A.M. Bilovol, N.L. Kolhanova

Kharkiv National Medical University

\section{Abstract}

The presence of diseases of the gastrointestinal tract, metabolic disorders, endocrine pathology affects the course of chronic dermatoses and the formation of clinical symptoms.

Objective, materials and methods. An assessment of the some indicators levels of the lipid profile (total cholesterol [TC], $L D L-C$ and $H D L-C$ ) in patients with typical and atypical forms of lichen planus (LP) are shown in this article. We observed 59 patients with LP aged 18 to 67 years. The control group consisted of 18 healthy persons that were representative by age and gender.

Results and conclusions. An increase of the levels of TC and LDL-C in patients with LP was established.

Key words: lichen planus, comorbidity, lipid profile, typical and atypical forms of lichen planus.

\section{Відомості про авторів:}

Біловол Алла Миколаївна - д-р мед. наук, професор, завідувач кафедри дерматології, венерології і медичної косметології Харківського національного медичного університету.

Колганова Наталія Леонідівна - аспірант кафедри дерматології, венерології і медичної косметології Харківського національного медичного університету; email: kolganova_natali@ukr.net. 